\title{
A Contribution to the Knowledge of the Torymidae (Hymenoptera, Chalcidoidea) from South-Western Iran
}

\author{
M. FALLAHZADEH ${ }^{1 *}, \mathrm{~S}_{\text {. AZADI }}{ }^{1}$ and P. JANŠTA ${ }^{2}$ \\ ${ }^{1}$ Department of Entomology, Jahrom Branch, Islamic Azad University, Jahrom, Iran \\ ${ }^{2}$ Department of Zoology, Charles University in Prague, Viničná 7, 12844 Prague 2, Czech Republic
}

(Received: 11 May 2015; accepted: 18 July 2015)

\begin{abstract}
New data on distribution of 11 torymid wasp species (Hymenoptera, Chalcidoidea, Torymidae) from Fars province in South-Western Iran are provided. The genus Eridontomerus Crawford, 1907 and four species Adontomerus nesterovi Zerova, 1985, E. biroi Ruschka, 1923, Monodontomerus rugulosus Thomson, 1876 and Podagrion gibbum Bernard, 1938 are new records for Iran. Available data for each species and brief notes on host(s) and geographical distribution are also given.
\end{abstract}

Keywords: Torymidae, Hymenoptera, Iran, fauna, distribution.

The family Torymidae (Hymenoptera, Chalcidoidea) is distributed worldwide and contains two subfamilies with 67 genera and about 1100 extant species (Noyes, 2015). Torymidae have a large number of niches and feeding habits. Most species of Megastigminae are phytophagous (seed-feeders) with a few entomophagous species, whereas species of Toryminae are primarily entomophagous. Some Toryminae are known as ectoparasitoid of gall-forming insects, parasitoids of mantid egg-cases, larvae of solitary bees and hyperparasitoid of butterflies' pupae (Askew, 1965, 1966, 2006b; Grissell, 1995, 2005; Janšta et al., 2013; Noyes, 2015).

The Iranian fauna of the Torymidae has been poorly studied. The first catalog of the Torymid wasp fauna of Iran was published by Peck (1963). Later, a few more species records of this family from Iran were added (e.g. Ebrahimi and Ahmadian, 2002; Lotfalizadeh and Gharali, 2005; Fallahzadeh et al., 2008; Stojanova and Ghahari, 2009) and a few new species described (e.g. Askew et al., 2006a; Zerova and Seryogina, 2008; Zerova et al., 2008). Fallahzadeh et al. (2009) provided a comprehensive check-list of the Iranian Torymidae consisting of 15 genera and 41 species of Torymidae. More recently, Madjdzadeh et al. (2013) and Lotfalizadeh (2014) added some new records from Iran.

Here, we provide further data on Torymidae in South-West Iran, add one genus and three species to the published records.

\footnotetext{
* Corresponding author; e-mail: mfalahm@yahoo.com
} 


\section{Materials and Methods}

The specimens were collected using Malaise traps in different locations (i.e. Fasa, Kherameh and Larestan) in Fars province, Iran (Table 1). The voucher specimens are deposited in Department of Entomology, Jahrom Branch, Islamic Azad University, Jahrom, Iran (JIAU) and in Charles University in Prague, Czech Republic (CUPC). The taxonomy and distributional data were adapted from Graham and Gijswijt (1998), Grissell (1995) and Noyes (2015).

Table 1

List of the sampling localities in the Fars province of Iran

\begin{tabular}{cllcl}
\hline No. & \multicolumn{1}{c}{ Locality } & \multicolumn{1}{c}{ Coordinates } & Altitude $(\mathrm{m})$ & \multicolumn{1}{c}{ Habitat } \\
\hline 1 & Kherameh & $29^{\circ} 30^{\prime} 42^{\prime \prime} \mathrm{N}, 53^{\circ} 18^{\prime} 55^{\prime \prime} \mathrm{E}$ & 1588 & Punica granatum \\
2 & Kherameh & $29^{\circ} 30^{\prime} 51^{\prime \prime} \mathrm{N}, 53^{\circ} 18^{\prime} 40^{\prime \prime} \mathrm{E}$ & 1588 & Punica granatum \\
3 & Larestan & $27^{\circ} 13^{\prime} \mathrm{N}, 54^{\circ} 25^{\prime} \mathrm{E}$ & 777 & Citrus aurantium \\
4 & Fasa & $28^{\circ} 53^{\prime} 06^{\prime \prime} \mathrm{N}, 53^{\circ} 40^{\prime} 36^{\prime \prime} \mathrm{E}$ & 1311 & Medicago sativa \\
5 & Fasa & $28^{\circ} 54^{\prime} 29^{\prime \prime} \mathrm{N}, 53^{\circ} 39^{\prime} 35^{\prime \prime} \mathrm{E}$ & 1343 & Punica granatum \\
6 & Fasa & $28^{\circ} 54^{\prime} 21^{\prime \prime} \mathrm{N}, 53^{\circ} 39^{\prime} 46^{\prime \prime} \mathrm{E}$ & 1366 & Citrus sinensis \\
7 & Fasa & $28^{\circ} 54^{\prime} 47^{\prime \prime} \mathrm{N}, 53^{\circ} 39^{\prime} 25^{\prime \prime} \mathrm{E}$ & 1348 & Punica granatum \\
\hline
\end{tabular}

\section{Results}

The following species of Torymidae were collected and identified during this study:

\section{Subfamily Toryminae Walker, 1833 \\ Tribe Microdontomerini \\ Genus Adontomerus Nikol'skaya, 1955}

\section{Adontomerus nesterovi Zerova, 1985}

Material examined: 1\%, Fars province, Fasa, 285'06"N, 5340'36"E, 3.VI.2013, Malaise-trap in Medicago sativa L. field, leg. S. Azadi; 1Q, 27.VI.2013; 1Q, 30.VI.2013; 1\%, 9.VII.2013; 1o, 11.VII.2013, same data; 1Q, Fasa, 28 54'21"N, 5339'46"E, 22. VI.2013, Malaise-trap in Citrus sinensis (L.) garden, leg. S. Azadi; 1ᄋ, 30.VI.2013; 1O, 4.VII.2013; 1Q, 9.VII.2013, same data; 1O, Fasa, 2854'29"N, 5339'35"E, 27.VI.2013, Malaise-trap in Punica granatum L. garden, leg. S. Azadi; 1ᄋ, 4.VII.2013; 19, 5.VII.2013; 1\%, 10.VII.2013, same data; 1\%, Fasa, 28 54'47"N, 53³9'25"E, 4.VII.2013, P. granatum garden, leg. S. Azadi; 1O, 17.VI.2013, same data.

Distribution: Turkmenistan, former USSR (Grissell, 1995; Noyes, 2015).

Comments: The genus Adontomerus comprises 11 described species (Noyes, 2015), and is an Old World genus (Grissell, 1995). Adontomerus nesterovi is a primary 
parasitoid of Paranthidiellum lituratum (Panzer) (Hymenoptera, Apoidea, Megachilidae) (Zerova and Seregina, 1992).

Until now, the Adontomerus species recorded from Iran were A. confusus Askew, 2000, A. crassipes (Bouček, 1982) and A. impolitus (Askew and Nieves Aldrey, 1988) (Fallahzadeh et al., 2009). In the present study, A. nesterovi is a new species record for Iran.

\section{Genus Eridontomerus Crawford, 1907}

\section{Eridontomerus biroi Ruschka, 1923}

Material examined: 2Q, Fars province, Fasa, 28 $54^{\prime} 47^{\prime \prime} \mathrm{N}, 5^{\circ} 39^{\prime} 25^{\prime \prime} \mathrm{E}, 7 . \mathrm{VI} .2013$, Malaise-trap in Punica granatum L. garden, leg. S. Azadi.

Distribution: Czech Republic, Hungary, Kazakhstan, Moldova, Romania, Slovakia (Grissell, 1995; Zerova and Seryogina, 1999; Noyes, 2015).

Comments: Eridontomerus is an Old World genus containing 12 species with one species which has apparently been introduced into the Nearctic region (Peck, 1963). Species of this genus appear to be parasitoids of gall-inducing Eurytomidae (Hymenoptera) and Cecidomyiidae (Diptera) in grass stems (Poaceae) (Noyes, 2015).

Zerova and Seryogina (1999) reared E. biroi from Tetramesa linearis (Walker) (Eurytomidae) from stems of Elytrigia sp., Calamagrostis sp., Elymus junceus Fisch. and Elymus angustatum Bieb. This parasitoid represents a new genus and species record for Iran.

\section{Genus Idiomacromerus Crawford, 1914}

\section{Idiomacromerus cf. korneyevi Zerova and Seryogina, 2001}

Material examined: 1Q, Fars province, Fasa, 28 $54^{\prime} 29^{\prime \prime} \mathrm{N}, 5^{\circ} 39^{\prime} 35^{\prime \prime E}, 30 . I V .2013$, Malaise-trap in Punica granatum L. garden, leg. S. Azadi; 1Q, Fasa, 28 54'47"N, 5339'25"E, 7.VI.2013, Malaise-trap in P. granatum garden, leg. S. Azadi; 1 , Kherameh, $29^{\circ} 30^{\circ} 51^{\prime \prime N}$, $53^{\circ} 18^{\circ} 40^{\prime E}$, 12.VI.2013, Malaise-trap in P. granatum garden, leg. E. Izadi; 1o, Kherameh, $29^{\circ} 30^{‘} 42^{\prime \prime} \mathrm{N}, 53^{\circ} 18^{\prime} 55^{\prime} \mathrm{E}, 15 . \mathrm{VI} .2013$, Malaise-trap in $P$. granatum garden, leg. E. Izadi.

Comments: The genus Idiomacromerus contains 44 species and is well represented in the Holarctic region from where more than half the known species have been recorded (Noyes, 2015). Species of the genus has been reared from various gall-forming and seed-feeding insects (Grissell, 1995; Noyes, 2015). Zerova and Seregina (2001) reported I. korneyevi in association with Nitraria schoberi (Zygophyllaceae).

\section{Genus Microdontomerus Crawford, 1907}

\section{Microdontomerus annulatus (Spinola, 1808)}

Material examined: 1Q, Fars province, Fasa, 2854'29"N, 53³9'35"E, 10.IV.2013, Malaise-trap in Punica granatum L. garden, leg. S. Azadi; 1Q, 20.IV.2013, same data; 1o, Fasa, 28 54'47"N, 5339'25"E, 18.IV.2013, Malaise-trap in P. granatum garden, leg. S. Azadi; 1o, 30.V.2013, same data; 1o, Fasa, 2853'06"N, 5340'36"E, 20.V.2013, Malaise-trap in Medicago sativa L. field, leg. S. Azadi. 
Iranian records: Ilam province (Gharali, 2004; Lotfalizadeh and Gharali, 2005), Tehran province (Modares Awal, 1997), Ghom province (Keyhanian, 2008), Guilan and Mazandaran provinces (Stojanova and Ghahari, 2009), Kurdistan province (Nazemi Rafie and Lotfalizadeh, 2012), Kerman province (Madjdzadeh et al., 2013).

Distribution: Austria, Croatia, Czech Republic, Egypt, England, France, Germany, Hungary, Iran, Italy, Libya, Moldova, Montenegro, Pakistan, Romania, Serbia, Slovakia, Spain, Sweden, Transcaucasus, Turkey (Noyes, 2015).

Comments: The genus Microdontomerus comprises 24 species and appears to be particularly well represented in the New World from where 19 species have been recorded (Grissell, 2005). Several species of the genus have been reared from various gall-forming insect and some species are parasitoids of a wide range of insects in all life-stages (Grissell, 2005; Noyes, 2015). In Iran, it has been reared from Acanthiophilus helianthi Rossi (Diptera, Tephritidae) on safflower Carthamus tinctorius and C. lanatus (Lotfalizadeh and Gharali, 2014).

\section{Tribe Monodontomerini Genus Monodontomerus Westwood, 1833}

\section{Monodontomerus obscurus Westwood, 1833}

Material examined: 1Q, Fars province, Fasa, 285'ㄴ' $11^{\prime \prime N}, 53^{\circ} 39^{\prime} 46^{\prime \prime E}, 26 . I V .2013$, Malaise-trap in Citrus sinensis (L.) garden, leg. S. Azadi.

Iranian records: Ardabil province (Lotfalizadeh and Gharali, 2005), Fars, Hamadan, Isfahan, Khorasan Shomali, Khorasan Jonobi, Mazandaran provinces (Stojanova and Ghahari, 2009), Kurdistan province (Nazemi Rafie and Lotfalizadeh, 2012), Kerman province (Madjdzadeh et al., 2013).

Distribution: Azores, Bulgaria, Canada, Chile, Croatia, Czech Republic, Denmark, Egypt, France, Germany, Hungary, India, Israel, Italy, Kazakhstan, Lebanon, Moldova, the Netherlands, Pakistan, Republic of Macedonia, Romania, Russia, Slovakia, Spain, Sweden, Switzerland, Turkey, Turkmenistan, Ukraine, United Kingdom, United States of America (Noyes, 2015).

Comments: The genus Monodontomerus contains 45 species and is widespread thought in the Holarctic region (Grissell, 1995; Noyes, 2015). Zerova and Seryogina (2002) revised of old world Monodontomerus species.

Some species of the genus are parasitoids of several families of Diptera, Hymenoptera and Lepidoptera and other develop in the cell of solitary bees and wasps (Narendran, 1994; Grissell, 1995). In the Palearctic region, some species Megachilidae, Vespidae, Sphecidae and Anthophoridae have been recorded as host for M. obscurus (Noyes, 2015).

\section{Monodontomerus rugulosus Thomson, 1876}

Material examined: 1Q, Fars province, Fasa, 2854'47"N, 53³9'25"E, 9.VII.2013, Malaise-trap in Punica granatum garden, leg. S. Azadi

Distribution: Armenia, Austria, Caucasus, Colombia, Czech Republic, France, Moldova, the Netherlands, Slovakia, Sweden, United Kingdom, former USSR (Noyes, 2015). 
Comments: Up to now, the Monodontomerus species recorded from Iran were M. aeneus (Fonscolombe, 1832), M. aereus Walker, 1834, M. obscurus Westwood, 1833 and M. vicicellae (Walker, 1847) (Fallahzadeh et al., 2009). In the present study, M. rugulosus is a new species record for Iran.

\section{Genus Oopristus Steffan, 1968}

\section{Oopristus turkestanicus (Skriptshinsky, 1929)}

Material examined: 10", Fars province, Fasa, 2854'29"N, 53³9'35"E, 4.VI.2013, Malaise-trap in Punica granatum L. garden, leg. S. Azadi.

Iranian records: Tehran province (Steffan, 1968), Iran (Farooqi, 1986).

Distribution: Iran, Iraq, Pakistan, Turkey, Uzbekistan (Noyes, 2015).

Comments: The genus Oopristus contains three described species with area of distribution restricted to Iran, Iraq, Pakistan and Uzbekistan (only O. turkestanicus; Bouček, 1978; Grissell, 1995; Noyes, 2015), Turkey (all three species; Tarla et al., 2010). Oopristus turkestanicus is an egg parasitoid of Apodiphus amygdali (Germar, 1817) and Sarju eremica (Hoberlandt, 1959) (Hemiptera: Pentatomidae) on various trees (Grissell, 1995; Tarla et al., 2010; Noyes, 2015).

\section{Tribe Podagrionini \\ Genus Podagrion Spinola, 1811}

\section{Podagrion gibbum Bernard, 1938}

Material examined: 1 , Fars province, Larestan, $27^{\circ} 13^{\prime} \mathrm{N}, 54^{\circ} 25^{\prime} \mathrm{E}, 4 . \mathrm{IX} .2012$, Malaise-trap in orange garden, leg. A. Falahatpishe.

Distribution: France, Greece, Romania, Spain (Noyes, 2015).

Comments: The torymid genus Podagrion is a moderately large and cosmopolitan genus of Podagrionini that currently consists of over 100 nominal species (Grissell, 1995; Noyes, 2015). In the Palearctic region, only 11 species and 3 subspecies of this genus have been recorded (Grissell, 1995; Noyes, 2015). Delvare (2005) revised and keyed out all species of Podagrion from West-Palearctic region.

All species of Podagrion are parasitic on mantis egg cases (Narendran, 1994). P. gibbum were reared on egg case of Ameles decolor (Charpentier, 1825), A. spallanzania (Rossi, 1792), Iris oratoria (L., 1758) and Mantis religiosa (L., 1758) (Delvare, 2005; Noyes, 2015). In the current study, P. gibbum is a new species record for Asia and Iran.

\section{Genus Podagrionella Girault, 1914}

\section{Podagrionella lichtensteini (Picard, 1933)}

Material examined: 1Q, Fars province, Fasa, 285' $21^{\prime \prime}$ N, 5339'46"E, 10.IV.2013, Malaise-trap in Citrus sinensis (L.) garden, leg. S. Azadi; 1Q, 20.IV.2013, same data; 1Q, 28.IV.2013, same data; 1Q, 17.V.2013, same data; 1o, 19.V.2013, same data; 2Q, 3.VI.2013, same data; 2Q, Fasa, 28 54'29"N, 53³9'35"E, 20.IV.2013, Malaise-trap in Punica gra- 
natum L. garden, leg. S. Azadi; 2Q, 30.V.2013, same data; 1Q, Fars province, Fasa, 28 53'06"N, 5340'36"E, 15.IV.2013, Malaise-trap in Medicago sativa L. field, leg. S. Azadi; 1Q, 20.V.2013, same data; 1O, Kherameh, 2930'51"N, 5318'40"E, 2.V.2013, Malaise-trap in P. granatum garden, leg. E. Izadi; 2Q, 18.V.2013, same data; 1O, 29.V.2013, same data; 1o, 31.V.2013, same data; 1\%, Kherameh, 2930'51"N, 53¹8'40"E, 27.V.2013, Malaise-trap in P. granatum garden, leg. E. Izadi.

Iranian records: East Azerbaijan province (Lotfalizadeh and Gharali, 2005), Kurdistan province (Nazemi Rafie and Lotfalizadeh, 2012).

Distribution: Canary Islands, France, Kazakhstan, Spain (Noyes, 2015).

Comments: Doganlar and Doganlar (2009) reviewed and keyed out Podagrionella species from Palearctic region and described two new species from Turkey. Alongside Podagrion, species of the genus Podagrionella are parasitic on mantis egg case (Grissell, 1995; Noyes, 2015). Podagrionella lichtensteini has been reported before as egg parasitoid of Iris oratoria (L., 1758) (Mantidae) (Grissell, 1995; Noyes, 2015).

\section{Tribe Torymoidini}

Genus Torymoides Walker, 1871

\section{Torymoides kiesenwetteri (Mayr, 1874)}

Material examined: 1Q, Fars province, Fasa, 2853'06"N, 5340'36"E, 13.VI.2013, Malaise-trap in Medicago sativa L. field, leg. S. Azadi.

Iranian records: Mazandaran province (Stojanova and Ghahari, 2009), Kerman province (Madjdzadeh et al., 2013).

Distribution: Andorra, Bulgaria, Canary Islands, China, Croatia, Czech Republic, Egypt, France, Germany, Greece, Hungary, India, Italy, Macedonia, Madeira, Moldova, Nepal, Poland, Romania, Slovakia, Spain, Switzerland, Turkey, UK, Serbia, former Yugoslavia, Yemen - Socotra island (Janšta, 2012; Noyes, 2015).

Comments: Torymoides is a cosmopolitan genus contains over 56 described species (Noyes, 2015). The majority of Torymoides species appears to be associated with galls of Cecidomyiidae and Tephritidae (both Diptera) found on grass or trees (Grissell, 1995; Noyes, 2015). Torymoides kiesenwetteri has been reared from galls of one cecidomyiid species and over 15 fruit flies species (Noyes, 2015).

\section{Tribe Torymini Genus Torymus Dalman, 1820}

\section{Torymus cupreus (Spinola, 1808)}

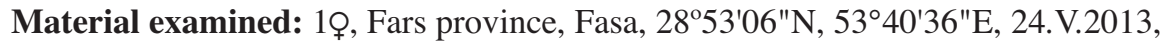
Malaise-trap in Medicago sativa L. field, leg. S. Azadi.

Iranian records: East Azarbaijan and Ghazvin provinces (Lotfalizadeh and Gharali, 2012; Lotfalizadeh, 2014).

Distribution: Austria, Burma, Caucasus, Croatia, Czech Republic, Denmark, Israel, Italy, Moldova, Montenegro, the Netherlands, Russia, Slovakia, Ukraine (Grissell, 1995; Noyes, 2015). 
Comments: Torymus is a worldwide, large genus contains about 412 described species (Noyes, 2015) with several phytophagous and many parasitoid species on a wide range of different insect life-stages (Grissell, 1995; Noyes, 2015).

\section{Discussion}

Altogether 11 species are listed with one genus and four species of Torymidae were reported for the first time from Iran. The result of this research and also that of many other researches, which were conducted on the fauna of Iranian Chalcidoidea, indicate that the fauna of Iranian Torymidae is rich and diverse that has not yet been thoroughly studied and needs more extensive investigation. In the present study Malaise trap were used for collecting torymid wasps, therefore their biology and host associations remain unknown. So, further study of their occurrence, distribution, biology, behavior and especially host specificity, should be supported.

\section{Acknowledgements}

The research was supported by Islamic Azad University, Jahrom Branch, Jahrom, Iran and Department of Zoology, Charles University in Prague, Czech Republic.

\section{Literature}

Askew, R. R. (1965): The biology of the British species of the genus Torymus Dalman associated with galls of Cynipidae on oak, with special reference to alternation of forms. T. Soc. Brit. Entomol. 16, 217-232.

Askew, R. R. (1966): Observations on the British species of Megastigmus Dalman (Hym. Torymidae) which inhabit cynipid oak galls. Entomologist 99, 124-128.

Askew, R. R., Sadeghi. S. E. and Tavakoli, M. (2006a): Chalcidoidea (Hym.) in galls of Diplolepis mayri (Schlechtendal) (Hym., Cynipidae) in Iran, with the description of a new species of Pseudotorymus masi (Hym., Torymidae). Entomol. Mon. Mag. 142, 1-6.

Askew, R. R., Plantard, O., Gómez, J. F., Hernandez Nieves, M. and Nieves-Aldrey, J. L. (2006b): Catalogue of parasitoids and inquilines in galls of Aylacini, Diplolepini and Pediaspidini (Hym., Cynipidae) in West Palaearctic. Zootaxa 1301, 1-60.

Bouček, Z. (1978): A study of the non-podagrionine Torymidae with enlarged hind femora, with a key to the African genera (Hymenoptera). J. Entomol. Soc. South. Afr. 41, 15-106.

Delvare, G. (2005): A revision of the west-Palearctic Podagrion (Hymenoptera: Torymidae), with the description of Podagrion bouceki sp. nov. Acta. Soc. Zool. Bohemoslov. 69, 65-88.

Doganlar, O. and Doganlar, M. (2009): Podagrionella Girault, 1913 (Hymenoptera: Torymidae: Podagrionidae) species from Turkey with descriptions of new species. Turk. J. Zool. 33, 181-186.

Ebrahimi, E. and Ahmadian, H. A. (2002): Report of Podagrion pachymerum (Hym., Torymidae) from Iran. Proceedings of 15th Iranian Plant Protection Congress, Vol. 1, Pests: 166.

Fallahzadeh, M., Shojai, M., Ostovan, H. and Kamali, K. (2008): The first report of Pseudotorymus stachidis (Hym.: Torymidae) from Iran. J. Ent. Soc. Iran 27, 17-18. (In Persian, English summary).

Fallahzadeh, M., Narendran, T. C. and Saghaei, N. (2009): Insecta, Hymenoptera, Chalcidoidea, Eurytomidae and Torymidae in Iran. Check List 5, 830-839. 
Farooqi, S. I. (1986): Family Torymidae. In: B. R. Suubba Rao and M. Hayat (eds): The Chalcidoidea (Insecta: Hymenoptera) of India and the Adjacent Countries. Part II, Oriental Insects, USA: Associated Publishers, $20,1-430$.

Gharali, B. (2004): Study of natural enemies of safflower shoot flies in Ilam province. Proc. of 16th Iranian Plant Protection Congress, Vol. 1, Pests, 54.

Graham, M. W. R. de V. and Gijswijt, M. J. (1998): Revision of the European species of Torymus Dalman (s. lat.) (Hym.: Torymidae). Zool. Verhandel. 317, 1-202.

Grissell, E. E. (1995): Toryminae (Hymenoptera: Chalcidoidea: Torymidae): a redefinition, generic classification and annotated world catalogue of species. Memoirs on Entomology, International 2, 474 p.

Grissell, E. E. (2005): A review of North American species of Microdontomerus Crawford (Torymidae: Hymenoptera). J. Hymenopt. Res. 14, 22-65.

Janšta, P. (2012): Description of male of Leucospis insularis (Hymenoptera: Chalcidoidea: Leucospidae) with new records and checklist of Chalcidoidea of Socotra Island. Acta Entomol. Mus. Nat. Pragae 52, 517523.

Janšta, P., Krizkova, B., Vilímová, J. and Rasplus, J. Y. (2013): Description of a new genus, Chileana (Hymenoptera: Chalcidoidea: Torymidae), with four new species. Zootaxa 3745, 49-63.

Keyhanian, A. A. (2008): Seasonal abundance of the safflower fly, Acanthiophilus helianthi Rossi (Diptera: Tephritidae), and its infestation on safflower, Carthamus tinctorius L. in Ghom province. Pajouhesh and Sazandegi 78, 57-62. (In Persian, English summary).

Lotfalizadeh, H. (2014): New findings of two Torymus species (Hym.: Chalcidoidea, Torymidae) of $c u$ preus-group in Iran. Biharen Biologist 8, 124-125.

Lotfalizadeh, H. and Gharali, B. (2005): Introduction to the Torymidae fauna (Hymenoptera: Chalcidoidea) of Iran. Zool. Middle East 36, 67-72.

Lotfalizadeh, H. and Gharali, B. (2012): New data on the family Torymidae (Hym.: Chalcidoidea) in the northwest of Iran. Proc. of 20th Iranian Plant Protection Congress, Vol. 1, Pests, 188.

Lotfalizadeh, H. and Gharali, B. (2014): Hymenopterous parasitoids of safflower seed pests in Iran. Appl. Entomol. Phyt. 82, 1-11. (In English, Persian summary).

Madjdzadeh, S. M., Lotfalizadeh, H. and Abolhasanzadeh, F. (2013): The family Torymidae (Hymenoptera: Chalcidoidea) of Kerman province, Southeastern Iran, Biharean Biologist 7, 20-24.

Modares Awal, M. (1997): List of Agricultural Pests and Their Natural Enemies in Iran. (Revised edition). Mashhad: Ferdowsi University Press, Iran, 429 p.

Narendran, T. C. (1994): Torymidae and Eurytomidae of Indian subcontinent (Hymenoptera: Chalcidoidea). Zoological Monograph, Department of Zoology, University of Calicut, Kerala, India, 500 p.

Nazemi Rafie, J. and Lotfalizadeh, H. (2012): Identification and diversity of torymid wasps (Hym.: Chalcidoidea, Torymidae) of Kurdistan Province. Proc. of 20th Iranian Plant Protection Congress, Vol. 1, Pests, 105.

Noyes, J. (2015): Universal Chalcidoidea Database. World Wide Web electronic publication at http://www.nhm. ac.uk/entomology/chalcidoids/ accessed 15 January 2015.

Peck, O. (1963): A catalogue of the Nearctic Chalcidoidea (Insecta, Hymenoptera). - Can. Entomol., Supplement, 30, 1-1092.

Steffan, J. R. (1968): Observations sur Chalcedectus sinaiticus (MS.) et descriptions de C. balachowskyi sp.n. (Hym. Chalcedectidae) et d'Oopristus safavii gen.n., sp.n. (Hym. Torymidae), deux parasites d'importance économique en Iran. Entomophaga 13, 209-216.

Stojanova, H. and Ghahari, H (2009): Checklists of Iranian Eurytomidae and Torymidae (Hymenoptera, Chalcidoidea). Linz. biol. Beitr. 4, 845-862.

Tarla S., Doganlar, M. and Gözüaçik, C. (2010): The species of Oopristus Steffan, 1968 (Hymenoptera: Torymidae: Toryminae: Monodontomerini) of Turkey with descriptions of two new species. Turk. J. Zool. 34, 487-495.

Zerova, M. D. and Seregina, L. Y. (1992): A review of species of the genus Adontomerus Nikol'skaya (Hymenoptera, Torymidae) with description of a new species from Tajikistan. Entomol. Obozr. 71, 460-464. 
Zerova, M. D. and Seregina, L. Y. (2001): A new Palaearctic species of chalcid wasps of the genus Idiomacromerus (Hymenoptera, Torymidae). Zool. Zh. 80, 882-884.

Zerova, M. D. and Seryogina, L. Y. (1999): Torymid Chalcidoid Wasps (Hymenoptera, Chalcidoidea, Torymidae) of Tribes Podagrionini and Monodontomerini of the Ukrainian Fauna. Vestn. Zool., Supplement 12, The Schmalhausen Institute of Zoology, Kiev, 130 p. (in Russian).

Zerova, M. D. and Seryogina, L. Y. (2002): A revision of old world Monodontomerus (Hymenoptera: Chalcidoidea: Torymidae). Separate issue, National Academy of Sciences of Ukraine I.I. Schmalhausen Institute of Zoology, Kiev, 74 p.

Zerova, M. D. and Seryogina, L. Y. (2008): A review of palearctic species of the genus Pseuderimerus (Hymenoptera, Torymidae) with a description of one new species from Iran. Vestn. Zool. 42, 263-265.

Zerova, M. D., Seryogina, L. Y. and Karimpour, Y. (2008): New species of the chalcidoid wasps of the families Eurytomidae and Torymidae (Hymenoptera, Chalcidoidea) from Iran. Vestn. Zool. 42, 489-496. 